\title{
DETERMINANTS OF SMALLHOLDERS' ADOPTION OF OFF-SEASON VEGETABLE PRODUCTION TECHNOLOGY IN OKHALDHUNGA DISTRICT OF NEPAL
}

\author{
B. Kunwar ${ }^{1}$, D. Dhakal ${ }^{2}$ and H.K.Panta ${ }^{2}$ \\ ${ }^{1}$ Department of Agriculture, Nepal, \\ ${ }^{2}$ Institute of Agriculture and Animal Sciences, Tribhuvan University, Nepal
}

\begin{abstract}
Mid-hills of Nepal is potential for off-season vegetable production but still the number of offseason vegetable growers is few and production is nominal which cannot even fulfill the internal demand. This paper examines the factors that influence farm households' decisions for adoption of off-season vegetable production. Household questionnaires were administered to 100 farmers of Okhaldhunga district of Eastern mid-hill of Nepal. Probit regression model is used to determine the factors. The result showed that years of schooling, years of vegetable production, access to extension services, training received are the factors that significantly influence technology adoption decisions of farm households' in the study area. It is concluded that farm households' off-season vegetable production depend on socioeconomic characteristics of farm household and institutional effectiveness. We recommend that policies should be formulated to take advantage of factors that positively influence farmers' adoption decisions and to mitigate the negative ones.
\end{abstract}

Key words: Off-season vegetable, smallholders, adoption, Probit model, Household

\section{INTRODUCTION}

Agriculture is main economic activity of Nepalese people which provides employment to $66 \%$ of total population and contributes about 35\% to National GDP (MoAD, 2013). According to NLSS (2011) majority of households (76\%) are agricultural households. The average size of agricultural land area is 0.7 hectares. The current vegetable growing area in Nepal is 2,46,392 ha. Total production throughout the country is 33,01,684 Mt. However, the distribution of vegetables production is not uniform throughout the country, which is rather concentrated in the vicinity of large urban areas.

Off-season vegetable farming refers to the production of vegetables in unusual seasons by adopting suitable technologies and farm inputs to meet the market demand throughout the year. In Nepal, the diversified climatic conditions are suitable to produce various types of crops, including vegetables during different seasons. At present, more than two hundred vegetable species are grown in different places under various climate zones of Nepal. Experiences have shown that commercialization of existing farming practices with adoption of technologies for off-season vegetables production can improve the livelihood of the farmers (Prajapati, 2007). In commercializing the agriculture sector, offseason vegetable farming has played a vital role contributing to enhancement of economic status of the farmers of the hills of Nepal. It has been providing regular employment and income to the marginal farmers and their family members throughout the year by bringing economic gains (Panta, 2001).

There is wide market within and outside the country for offseason vegetable. Even during the season our current production cannot fulfill the internal market demand and large amount of vegetable are imported. This case is more worse during offseason and our market is dominanted by 
Indian vegetables. It was estimated that the per capita annual vegetable consumption in the early $1980 \mathrm{~s}$ was about $45 \mathrm{~kg}$ that reached to about $95 \mathrm{~kg}$ by the latest estimation. Still it is not sufficient to supply minimum requirement of $104 \mathrm{~kg}$ per person per year (VDD, 2013). This demand can be met either by expanding vegetable cultivation area or by intensifying the production of vegetables, including off-season vegetables production all the year round.

Considering the importance of horticultural crops in Nepal, Agricultural Prospective Plan (APP, 1995) has emphasized the development of this subsector in the kingdom based on comparative advantages under different bio-physical domains. The offseason vegetable production in hills is a categorically specified area in the APP. Eighth Five year plan also emphasized the offseason vegetable production in the mid hill which is also followed in subsiquent plans.

Farmers' decision on off-season vegetable production may be affected by numbers of biophysical as well as socio-economic factors. This paper examined important socio-economic factors affecting adoption of off-season vegetable production in Okhaldhunga district of eastern mid-hills of Nepal.

Rogers and Shoemaker (1971), Dasgupta (1989), and Rogers (1995), all stated that the adoption is the mental process through which an individual passes from the first stage of awareness or knowledge of an innovation to a decision to adopt or reject and to conformation of this decision.

Prajapati (2007) argues that adoption of off-season vegetable farming has not only improved in the life of the farmers-entrepreneurs themselves, but also brought about change in communities and the whole area itself. Off-season vegetable farming is one of the potential sources of income and reliable means for the reduction of poverty and malnutrition persisting over the hills of Nepal (AEC, 2006).

Many studies have viewed technology as a means to end poverty (Besley and Case, 1993). It is often claimed in the literature that the transfer of technologies through the adoption of modern varieties of seeds and fertilizers can substantially provide an opportunity to increase productivity and income (Feder, Just and Zilberman, 1985). The contribution of technological change to agricultural productivity in developing countries has been extensively documented ( Sunding and Zilberman, 2000; Doss, 2006).

Adoption and dissemination rates of new agricultural technologies in Nepal are relatively lower than in other South Asian countries due to Nepal's late participation in the Green Revolution (Herath and Jayasuriya, 1996). The major challenge on studies of adoption and diffusion of agricultural innovations is to understand the farmers' perception towards new technology and its impact on farm production (Doss, 2006).

Dasgupta (1989) stated that the findings on the relationship between the age of farmers and their adoption behaviour are somewhat inconsistent. Adopters tended to be younger in age than non adopters. Alam (1965), Joshi (1977) and Nirwal and Arya (1974) reported that it is the farmer of the middle age group (30-45) rather than of the young or old age groups which tended to show a greater tendency to adopt recommended farm practices. Contrary to this finding, Rai (1967), Aggarwal and Deb (1974), Basran (1968), Bose (1966) and Chand and Gupta (1966) noticed no relationship between age and adoption of improved agricultural practices.

Pandit (1964) and Rai (1967) observed that farmers with higher level of education were better adopters while Akhouri and Singh (1974), Reddy and Kivlin (1968) found no relation of education with the adoption of high yielding varieties of wheat and bajra. Singh and Reddy (1965) observed that the farmers who were literate had a significantly higher level of adoption than those who were non-literates, even though the level of formal education of farmers and their adopting behaviour were not related. 
Gogoi and Gogoi (1989) found that mass media exposure, size of operational land holding, knowledge level of farmers and extension contact had positive and significant contribution to adoption behavior of farmers. The age was found to have negative and significant contribution.

\section{The Survey}

\section{METHODOLOGY}

Altogether 100 samples were selected from four different VDCs of Okhaldhunga district. Samples were selected randomly. Household survey with the help of semi-structured interview schedule was used to collect information. Key informant interview was done to validate collected information. Collected data was analyzed by using statistical software STRATA (version 12).

\section{The analytical model: Probit model}

Probit model was used to identify determinants of off-season vegetable production decisions. In the Probit model, the households are assumed to make decisions based upon an objective of utility maximization. For a given decision, separate models are developed for each decision. The underlying utility function depends on household specific attributes $X$ (e.g. age of household head, sex of the household head, education, membership to an agricultural association, access to credit, etc) and a disturbance term having a zero mean:

$\mathrm{U}_{i 1}(\mathrm{X})=\beta_{1} \mathrm{X}_{i}+\varepsilon_{i 1}$ for adoption

And $\mathrm{U}_{i 1}(\mathrm{X})=\beta_{1} \mathrm{X}_{i}+\varepsilon_{i 1}$ for not adoption.

As utility is random, the $I^{\text {th }}$ household will select the alternative "adoption" if and only if $\mathrm{U}_{i 1}>\mathrm{U}_{i 1}$. Thus, for the household $i$, the probability of adoption is given by:

$$
\begin{aligned}
& \mathrm{P}(1)=\mathrm{P}\left(\mathrm{U}_{i 1}>\mathrm{U}_{i 1}\right) \\
& \mathrm{P}(1)=\mathrm{P}\left(\beta_{1} \mathrm{X}_{i}+\varepsilon_{i 1}>\beta_{1} \mathrm{X}_{i}+\varepsilon_{i 1}\right) \\
& \mathrm{P}(1)=\mathrm{P}\left(\varepsilon_{i 1}-\varepsilon_{i 1}<\beta_{1} \mathrm{X}_{i}-\beta_{1} \mathrm{X}_{i}\right) \\
& \mathrm{P}(1)=\mathrm{P}\left(\varepsilon_{i}<\beta_{1} \mathrm{X}_{i}\right) \\
& \mathrm{P}(1)=\varphi\left(\beta \mathrm{X}_{i}\right)
\end{aligned}
$$

Where, $\Phi$ is the cumulative distribution function of the standard normal distribution. The parameters $\beta$ are estimated by maximum likelihood is $x^{\prime}$ a vector of exogenous variables which explains adoption. In the case of normal distribution function, the model to estimate the probability of observing a farmer using a new technology can be stated as:

$$
p\left(y_{i}=1 \mid \mathrm{x}\right)=\Phi\left(\mathrm{x}^{\prime} \beta\right)=\int_{-\infty}^{x^{\prime} \beta} \frac{1}{\sqrt{2 \pi}} \exp \left(-z^{2} / 2\right) d z
$$

Where $\mathrm{P}$ is the probability that the $\mathrm{i}^{\text {th }}$ household used the new technology, and 0 otherwise. Thus, the Probit regression model is expressed as;

$Y($ adopter $=1)=\beta_{1}+\beta_{1}$ Age of HH head $+\beta_{2}$ Sex of HH head $+\beta_{3}$ Years of schooling $+\beta_{4}$ Major occupation $+\beta_{5}$ Total land holding $(\mathrm{Ha})+\beta_{6} \mathrm{HH}$ income from ag $+\beta_{7}$ Economically active population $+\beta_{8}$ Training $+\beta_{9}$ Access to extension service $+\ldots \ldots \ldots \ldots+\varepsilon_{i}$

Where, Y means adopters are those who grow offseason vegetables is dependent variable. 
According to Nagler (2002) probit model contains the estimated probabilities to be between 0 and 1 and relaxes the constraint that the effect of the independent variable is constant across different predicted values of the dependent variables. This is normally experienced with the Linear Probability Model. The advantage of the probit model is that it includes believable error term distribution as well as realistic probabilities (Nagler, 1994).

Table 1. Different variables used in probit analysis and their expected signs

\begin{tabular}{lc}
\hline Variables & Expected sign \\
\hline Age of household Head (years) & - \\
Sex of household head (male=1, female=0) & + - \\
Economically active member (number) & + \\
Years of schooling (years) & + \\
Major occupation (Agriculture=1, else=0) & + \\
Irrigation facility (Yes=1, No=0) & + \\
Years of vegetable cultivation (Years) & + \\
Training (Received training=1, Not received training=0) & + \\
Access to extension (Yes=1, No=0) & + \\
Agricultural income of household (In NRs.) & + \\
\hline
\end{tabular}

\section{Socio-demographic characteristic of the respondents}

The total population of the sampled households was 521, out of which $54.31 \%$ were female and $45.69 \%$ were male. The average age of household head was 46.38 years which lies in economically active population. Among selected households, $63 \%$ were male headed and 37\% were female headed with average family size of 5.21 persons. Similarly, $57.96 \%$ of the populations were economically active population. Majority of household head (79\%) were engaged in agriculture as major occupation. Only 14\% of adopters were illiterate as compared to $34 \%$ illiterate non-adopters in the study area. The average years of schooling of household head was 3.84 with standard deviation of 3.82. Among the household heads of the study area $56 \%$ were participated in training related to agriculture. Of the total households $63 \%$ had received extension services in different forms while 37 $\%$ lack extension services. The average land holding in the study area was 0.57 hectare.

\section{Factors affecting decision on off-season vegetable production}

To identify the factors affecting farmers' decision on off-season vegetable production in Okhaldhunga district, Probit regression model was used. Respondents were found either growing offseason vegetables or seasonal vegetable or not growing vegetables at all. The adopters were categorized based on binary response. The respondent growing off-season vegetables were designated as adopters (1) and else were designated as non- adopter (0). 
Table 2. Summary statistics of probit regression analysis

\begin{tabular}{lc}
\hline Number of observation & 100 \\
\hline Log likelihood & -9.802 \\
LR chi' $^{2}(10)$ & 117.58 \\
Prob>chi & 0.000 \\
Pseudo R & \\
Cases predicted correctly (\%) & 0.851 \\
\hline
\end{tabular}

The Pseudo $\mathrm{R}^{2}$ was 0.851 (Table 2) which implies that the variables included in the model are able to explain $85 \%$ of probability of household decisions to adopt or not adopt off-season vegetable production. The Log-likelihood Ratio (LR) was found to be significant at 1\% level (Table 2). This means that all the explanatory variables included in the model jointly influence farmers' probability of adoption of off-season vegetable production. The model results also gave a predicted probability of adoption to be 0.7889 . This means that there is about $79 \%$ probability that farm household in the study area are willing to grow off-season vegetable provided some socio-economic and institutional bottlenecks that hinders adoption are addressed. Thus model can be said consistent and meaningful.

The dependent variable i.e. adoption of off-season vegetable production was regressed upon the ten independent variables namely age of household head, sex of household head, economically active members, years of schooling, major occupation, irrigation facility, years of vegetable cultivation, training received, access to extension and agriculture income of household. Among these factors, probit regression analysis showed four variables (years of schooling, years of vegetable cultivation, training received and access to extension) to be statistically significant for the adoption of off-season vegetable production on study area (Table 3).

Table 3. Factors affecting the off-season vegetable production in the study area (2013)

\begin{tabular}{llllll}
\hline Variable & Coefficients & $\mathrm{P}>|\mathrm{z}|$ & $\begin{array}{l}\text { Standard } \\
\text { error }\end{array}$ & dy/dx $^{\mathrm{b}}$ & S.E. $^{\mathrm{b}}$ \\
\hline Age of household Head(years) & -0.010 & 0.823 & 0.044 & -0.003 & 0.012 \\
Sex of household head (male=1, female=0) & 0.319 & 0.726 & 0.911 & 0.095 & 0.273 \\
Economically active member (number) & -0.232 & 0.575 & 0.415 & -0.067 & 0.128 \\
Years of schooling (years) & $0.218^{*}$ & 0.098 & 0.132 & 0.063 & 0.444 \\
Major occupation (Agriculture=1, else=0) & 1.216 & 0.339 & 1.273 & 0.415 & 0.485 \\
Irrigation facility (Yes=1, No=0) & 0.140 & 0.894 & 1.048 & 0.041 & 0.323 \\
Years of vegetable cultivation (Years) & $0.367^{* *}$ & 0.029 & 0.168 & 0.106 & 0.050 \\
Training (Received training=1, Not received & $2.102^{* *}$ & 0.049 & 1.068 & 0.604 & 0.258 \\
training=0) & $1.530^{* *}$ & 0.025 & 0.684 & 0.478 & 0.251 \\
Access to extension (Yes=1, No=0) & 0.000 & 0.133 & 0.000 & 0.001 & 0.000 \\
Agricultural income of household (In NRs.) & -5.492 & 0.060 & 2.925 & - & - \\
Constant & & & & \\
\hline
\end{tabular}

***Significance at $\mathrm{P}=0.01$; ** Significant at $\mathrm{P}=0.05$; * Significance at $\mathrm{P} \geq 0.1$

${ }^{\mathrm{b}}$ Marginal change in probability (marginal effect after Probit) evaluated at the sample means 
The sign of years of schooling was as expected and positively significant $(\mathrm{P}<0.10)$ which implies that adoption increases with the increase in years of schooling. The coefficient of education was expected positive to decrease risk aversion behavior and increase adoption. Table 3 explains that with 1 year increase in year of schooling the chances of adoption off-season vegetable production increases by $6.3 \%$ others things remaining constant. This is consistent with the literature that education creates a favorable mental attitude for the acceptance of new practices especially of informationintensive and management-intensive practices (Waller et al, 1998; Caswell et al, 2001). Similarly the result is consistent with the findings of Adhikary (1994), Asfaw and Admassie (2004), Kattel (2009), Ward et al. (2009).

The coefficient of years of vegetable cultivation (i.e. experience of farmers) was positive and significant at 5\% level. As the farmers gain knowledge, skill and experience from seasonal vegetable production, they start to shift towards off- season vegetables production. The more the experience of farmers in vegetable cultivation more is the level of adoption of off-season vegetable production. Table 3 shows that with one year increase in vegetable cultivation the adoption of off-season vegetable production increases by $10.6 \%$.

Training received was found positively significant at 5\% level. It means that the level of growing off-season vegetable increases with training facilities. Adoption of off-season vegetable production increases by $60.4 \%$ if the farmers are provided training facilities. This reveals that offseason vegetable production is technology intensive and farmers need training to enhance skill to grow off-season vegetables. This result is in line with the Rosegrant and Cline, (2003) and Feder, (1987).

Access to extension services is critical in promoting adoption of modern agricultural production technologies because it can counter balance the negative effect of lack of years of formal education in overall decisions to adopt some technologies (Yaron et al., 1992). Access to extensions services therefore creates the platform for acquisition of the relevant information that promotes technology adoption. Access to information through extension services reduces the uncertainty about a technology's performance hence may change individual's assessment from purely subjective to objective over time thereby facilitating adoption. Related to this is access to extension services which was also found to be positively related to the adoption of off- season vegetable production technologies and was found to be significant at 5\% level. This means that farm households are more likely to adopt off-season vegetable production technologies if they have access to extension services. As extension service popularizes the innovation by providing necessary information, knowledge and skills in order to enable farmers to apply innovation. Majority of the farmers in rural areas of Nepal have not been able to obtain technological information due to lack of know-how, transportation facilities, access to communication media and technical training. This finding is in conformity with other studies (Abebaw and Belay, 2001).

\section{CONCLUSION}

Adoption of off-season vegetable farming is found to be affected by socioeconomic and institutional characteristic of the households. Mainly four factors viz. years of schooling, years of vegetable farming, access to extension services and training received are found significant. Thus, we can conclude that educated people are attracted to off-season farming and experienced vegetable growers tend to shift towards off-season vegetable cultivation. It is recommended to increase 
extension services and training related to improved production technology for better adoption of offseason vegetable cultivation.

\section{REFERENCES}

AEC. 2006. Off-season vegetables. Agro Enterprise Centre/ Federation of Nepalese Chamber of Commerce and Industry, Teku, Kathmandu, Nepal.

Agarawal, B. K. and P. C. Deb. 1974. Socio-economic context of differential agricultural development. A case study in Punjab. Journal of Social and Economic Studies 2:35-46.

Alam, Md. O. 1965. Characteristics of progressive farmers. Indian Journal of Adult Education 35 : 96-97.

Akhouri, M. M. P. and K. P. Singh. 1974. Adoption of high-yielding varieties as a function of assured irrigation, holding size and education. Indian Journal of Adult Education 35: 96-97.

Besley, T. and A. Case. 1993. Modelling technology adoption in developing countries. American Economic Review 83 (2): 396-402.

Bose, A.B. 1966. Relative importance of some socio-economic factors in the adoption of innovations. Indian Journal of Social Research 7: 8-13.

Basran, G. S. 1968. Factors related to acceptance of new ideas and techniques in farming in Punjab. Indian Journal of Extension Education 4: 29-39.

CBS. 2010. Nepal vegetable crop survey. National Planning Commission Secretariat, Government of Nepal.

CBS. 2011. Nepal Living Standard Survey. Nepal Government, Kathmandu, Nepal.

Chand, R. and M. L. Gupta. 1966. A study of the adoption of improved farm practices and their characteristics. Indian Journal of Extension Education 1: 259-267.

DADO 2012. Annual agricultural development programme and statistics: a view. District agriculture development office Okhaldhunga, Nepal.

Dasgupta, S. 1989. Diffusion of agricultural innovations in village India. Wiley Western Limited. New Delhi.

Doss, C. R. 2006. Analyzing technology adoption using micro-studies: limitations, challenges, and opportunities for improvement. Agricultural Economics 34: 207- 219.

Feder, G., R. Just and D. Zilberman. 1985. Adoption of agricultural innovations in developing countries: A survey. Economic Development and Cultural Change 33: 255-297.

Gogoi, S. K. and D. K. Gogoi. 1989. Adoption of recommended plant protection practices in Rice: A multivariate analysis. Indian Journal of Extension Education 25: 26-29.

Greene, W. H. 2003. Econometric Analysis. Fifth Edition, NJ: Prentice Hall.

Gujrati, D. N. 1995. Basic Econometrics.3rd Edition, McGraw Hill Inc. New York, USA, pp 553570.

Joshi, P. L. 1977. Adoption of some chemical fertilizers and improved manuring techniques in a village in Western Rajastan. Indian Journal of Social Research 13: 145-51.

MOAD. 2012. Available at: http//www.moad.gov.np (Retrieved on 01/01/2014).

Nagler, J. 2002. Interpreting probit analysis. New York University.

Nagler, J. 1994. Interpreting probit analysis. New York University.

NLSS-III, 2011. National Living Standard Survey -III, Government of Nepal, National Planning Commission Secretariat, Central Bureau of Statistics, Ramshahpath, Kathmandu, Nepal. 
Nirwal, R. S. and B. S. Arya. 1974. Who adopt improved farm practices? Indian Journal of Adult Education 35: 59-51.

Panta, S. 2001. Final Report on Commercial Off-Season Vegetable Production and Marketing Program (1997-2001). Agro Enterprise Centre, FNCCI, Kathamandu, Nepal.

Pandit, S. 1964. Study of the role of age, education, and size of farm in relation to adoption of improved agriculture practices. Resource Foundations Bull 6: 70-73.

Prajapati, B. 2010. Study on the Off-Season Vegetables Farming and its Impact on Socio-Economic Development: A Case Study of Rasuwa District Micro Enterprise Development Program.

Rai, H. N. 1967. Diffusion of information and farmers' responses to an improved farm practices. Resource Foundations Bull, 8: 118-121.

Reddy, S. K. and J. E. Kilvin. 1968. Adoption of high-yielding varieties: A Study in three Indian villages. Behavioural Sciences and Community Development 2: 121-42.

Rogers, E. M. and F. F. Shoemaker. 1971. Communication of innovations. $2^{\text {nd }}$ edition. The Free Press, a Division of Macmillan Publishing Co., Inc. New York. pp 100-156. 